\title{
China's Perception of Risk and the Concept of Comprehensive National Power
}

\author{
SEAN GOLDEN
}

\begin{abstract}
This article approaches the concept of risk from a Chinese perspective and traces its evolution throughout the history of Chinese thought, from the classics to the present. It analyzes underlying elements that have given rise to its current form, in comparison with elements of the same concept in the West, and describes how the perception of risk has helped shape the guidelines of China's ongoing transformation, as in the case of 'peaceful development' and a 'harmonious world'. It identifies the main domestic and foreign risks that threaten the sustainability of China's development, and discusses the concept of 'comprehensive national power'.
\end{abstract}

Keywords: China, risk, comprehensive national power

The standard definition of risk ponders the probability of something happening with the cost of its happening. In this sense, a high probability with a low cost is not as much a risk as a lower probability with a higher cost. In 1662, the monastery of Port Royal published the following definition of risk in the anonymous Ars Cogitandi text: 'Fear of harm ought to be proportional not merely to the gravity of harm, but also to the probability of the event' (Hacking 1975: 77; Bernstein 1998: 383; Bosch-Domènech \& Silvestre i Benach 2005). A useful strategy for risk analysis is forecasting possible risk scenarios, calculating their cost, and designing possible responses (risk management). This is the strategy known as 'Murphy's Law': if something can go wrong it will go wrong (with its corollary: if something can go wrong in more ways than one, it will go wrong in the worst way possible). Other popular versions of the strategy for managing risks are 'Plans $\mathrm{A}, \mathrm{B}$ and $\mathrm{C}^{\prime}$ (or more), or the best-case and worst-case scenarios and various scenarios in between. Risk analysis can be quantitative or qualitative, or a combination of both. For quantitative analysis, the factors to be considered are probability and cost; for qualitative analysis, they are threats and vulnerabilities on the one hand, and controls and countermeasures on the other. A special case is uncertainty, a source of risk that is not amenable to calculation. 
This article presents a Chinese perspective on risk calculation methods and examples of analyses that Chinese experts have made.

\section{Risk Scenarios in Classical Chinese Thought}

Classical Chinese culture embodied its vision of risk scenarios in the mid-first millennium BC in the text known as 孫子兵法 Sunzi bingfa (The Art of War [兵法] attributed to Sunzi [孫子]), which identifies five factors that determine victory or defeat in war (Table 1) (Sunzi bingfa; cf. Golden \& Presas 2007; Ramírez 2006; Minford 2002; Galvany 2001; Ames 1993; Griffith 1971).

TABLE 1: The Five Factors that Determine Victory or Defeat in Sunzi bingfa

\begin{tabular}{|l|l|}
\hline 道 dao & the way, the route, the authority or moral force of the ruler \\
\hline 天 tian & $\begin{array}{l}\text { the sky, daytime or night time, atmospheric conditions, the seasons, } \\
\text { the cosmos }\end{array}$ \\
\hline 地 $d i$ & the land, terrain, distances, sovereignty \\
\hline 將 jiang & the general, the chain of command \\
\hline 法 $f a$ & order, organization, military training, military discipline \\
\hline
\end{tabular}

Source: Sunzi bingfa, Chapter 1 . $^{2}$

The rulers and their military strategists pondered these five factors in the temple of the ancestors in order to ponder or calculate (算 suan) their weight relative to each side of combatants. Chinese strategists would appear to have invented a form of game theory three millennia ago:

Victory belongs to the side that has more points in the calculations made in the temple before entering into battle; defeat belongs to the side that has fewer points in the calculations made in the temple before entering into battle (Sunzi bingfa, Chapter 1).

Calculating factors such as the time of day, the weather and the climate or seasonal effects on the one hand, and those of terrain or distances on the other, would seem to be fairly objective. But it would also appear that they had methods for calculating non-empirical factors as well, such as the moral authority of the rulers that would guarantee loyalty from their subjects, the strategic ability of the generals and the efficacy of the military training and discipline of the troops. Could The Art of War be a precedent or a harbinger of the strategic capacity of China's leaders today?

An example of qualitative analysis that has become very well known is the following: 
Who knows the enemy as well as he knows himself will always win, even in 100 battles. Who does not know the enemy but does know himself will suffer one defeat for every victory. Who knows neither himself nor the enemy will lose every battle (Sunzi bingfa, Chapter 3).

At first glance, these statements seem to refer to psychological qualities, but they are repeated later in a different context that is entirely empirical, dedicated to the analysis of the terrain of the battlefield, the strong and weak points of the troops, the strategic value of the placement of the troops, etc.:

Know the enemy and know oneself and never doubt the victory, even in 100 battles. Know the Sky [atmospheric conditions, climate], know the Earth [terrains, distances], and every victory will be complete (Sunzi bingfa, Chapter 10).

The ability to envisage scenarios and calculate previsions for risks is defined in a key way as the relationship between a pair of correlative concepts (like 陰陽 yinyang) that constitute the essence of the calculations that a strategist must make: 利 $l i$ (profit, advantage) and 害 hai (damage, loss, disadvantage). The more benefit or advantage there is, the less loss or disadvantage, and vice versa. This correlation constitutes the essence of the calculations that a strategist should make:

A wise leader must consider the amalgam of advantage and disadvantage inherent in every situation. A leader capable of discerning the possible disadvantages of an apparently advantageous situation may be entrusted to carry out a plan. A leader capable of discovering the possible advantages of apparently disadvantageous circumstances will be capable of salvaging the situation (Sunzi bingfa, Chapter 8).

Sunzi bingfa repeatedly insists on flexibility and the necessity to adapt strategies and tactics to conditions that by their very nature are constantly changing. There are no fixed and permanent strategies and no strategy or tactic can be repeated exactly the same way because no two sets of conditions will ever be the same. Orthodox strategies are predictable, unexpected ones are not, although in some circumstances what might not be expected is precisely an orthodox response.

From the beginning, Chinese socio-political thought has shown a marked aversion to 亂 [乱] luan (disorder, chaos) (Guo 1975; Hsiao 1979; Louie 1986; He \& Bu 1998; Louie \& Hodge 1998). The graphic etymology of the Chinese character luan is a pair of hands unravelling a fabric. To change the direction of the People's Republic of China in the late 1970s, after the death of 毛泽东 Mao Zedong (1893-1976), Deng Xiaoping proposed a risk management strategy of 拨乱反正 boluan fanzheng, 'bring 
order out of chaos and return to rectitude' (Barmé 1993). This meant putting an end to the excesses of the Cultural Revolution and restoring political, economic and social development on the pragmatic basis of 不管白猫，黑猫，逮住老鼠就是好猫 buguan bai mao hei mao lizhu laoshu jiu shi hao mao, 'it does not matter whether the cat is white or black as long it catches mice', and the flexible experimentation of 摸着石头过河 mozhe shitou guohe, 'crossing the river by feeling for the stones'. In Deng's formulation for restoring order, which involves the pursuit of risk management strategies, the opposite of 乱 luan (disorder) is 正 zheng (order, rectitude). In general terms, however, the opposite of 乱 luan (disorder) in Chinese socio-political thought is 和 he (harmony, peace, coexistence). This is the same concept that animates the discourse of 胡锦涛 Hu Jintao today: 和谐社会 hexie shehui (harmonious society), 和谐世界 hexie shijie (harmonious world.) The major source for taking harmony as the basis for strategic thinking is Confucius. The Lunyu 論語 [论语] or 'Analects' that recorded his teachings give preference to harmony over force: 'Duke Huan brought the nine feudal lords together, not by the use of war chariots [military force], but through Guan Zhong's influence' (桓公九合 諸侯、不以兵車、管仲之力也, 論語 Lunyu XIV.17.2). For Confucius, 管 仲 Guan Zhong (d. 645 BCE) was an exemplary minister who governed on the basis of propriety, appropriateness, altruism and learning. 'The exemplary person seeks harmony but not uniformity; the petty-minded person seeks uniformity but not harmony' (君子和而不同、小人同而不和， 論語 Lunyu XIII.23). Another classical statement of the role of harmony in state affairs is attributed to 晏子 Yanzi (d. 493 BCE).

Harmony is the reconciling of differences into a harmonious unity. [The Confucian text 左傳 Zuo Zhuan] reports a speech by the statesman [Yanzi], in which he makes a distinction between harmony and uniformity or identity. Harmony, he says, may be illustrated by cooking. Water, vinegar, pickles, salt, and plums are used to cook fish. From these ingredients there results a new taste which is neither that of the vinegar nor of the pickles. Uniformity or identity, on the other hand, may be likened to the attempt to flavor water with water, or to confine a piece of music to one note. In both cases there is nothing new.... Herein lies the distinction between the Chinese words [同 tong] and [和 he]. [Tong] means uniformity or identity, which is incompatible with difference. Ho means harmony, which is not incompatible with difference; on the contrary, it results when differences are brought together to form a unity. ... A well-organized society is a harmonious unity in which people of differing talents and professions occupy their proper places, perform their proper functions, and are all equally satisfied and not in conflict with one another. An ideal world is also a harmonious unity (Fung 1960: 174). 


\section{Risk Scenarios in Contemporary Chinese Thought}

The Chinese term 危機 weiji (danger, risk, crisis) combines the concepts of 危wei (danger) and 機ji (opportunity). It refers to the critical moment of a situation - 時機shiji-and implicates the possibility of a positive as well as a negative result in a situation of risk. Every outcome depends on the specific analysis of potential risk scenarios and the planning and implementation of specific risk management strategies.

The analysis of risk scenarios from a Chinese perspective should be carried out in a double context: domestic and foreign. It should also consider the global implications of China's emergence as a new economic superpower. The varying paradigms and theoretical frameworks used to analyze this situation can produce different and sometimes contradictory results, as illustrated by the debate between 'the China threat' on the one hand, and 'peaceful rise' or 'peaceful development' on the other.

The 'emergence' of China as a world power should really be seen more as a 're-emergence', as evidenced by the statistics shown in Table 2 and Figure 1.

The fall in the share of world GDP experienced by China and India between 1820 and the mid-twentieth century (until well past independence in the case of India and the policy of reform and opening up in the case of China) traces a reverse curve to the growth of the share of world GDP in the hands of Western Europe and the United States during the same period and corresponds to the peak of the industrial revolution and of aggressive Euro-American imperialism. The projected growth for China and India to 2030 corresponds to a contraction projected for Western Europe and the US. If the Euro-American rise resulted from a

TABLE 2: China, Japan, India, Western Europe and the US, 1820-2030 (Percentage of World Gross Domestic Product)

\begin{tabular}{|c|c|c|c|c|c|}
\hline Year & China & Japan & India & $\begin{array}{c}\text { Western } \\
\text { Europe }\end{array}$ & US \\
\hline $\mathbf{1 8 2 0}$ & 33.0 & 3.0 & 16.0 & 17.0 & 2.0 \\
\hline $\mathbf{1 9 1 3}$ & 9.0 & 3.0 & 7.0 & 33.0 & 19.0 \\
\hline $\mathbf{1 9 5 0}$ & 5.0 & 3.0 & 4.0 & 26.0 & 27.0 \\
\hline $\mathbf{1 9 7 8}$ & 4.9 & 7.6 & 3.3 & 21.5 & 21.7 \\
\hline $\mathbf{2 0 0 1}$ & 12.0 & 7.0 & 5.0 & 20.0 & 21.0 \\
\hline $\mathbf{2 0 3 0}$ & 18.4 & 4.0 & 10.0 & 13.0 & 17.7 \\
\hline
\end{tabular}

Sources: Maddison 2003, Hu 2005.

Note: Values calculated in Geary-Khamis 1990 international dollars. 
FIGURE 1: China, Japan, India, Western Europe and the US, 1820-2030 (Percentage of World Gross Domestic Product)

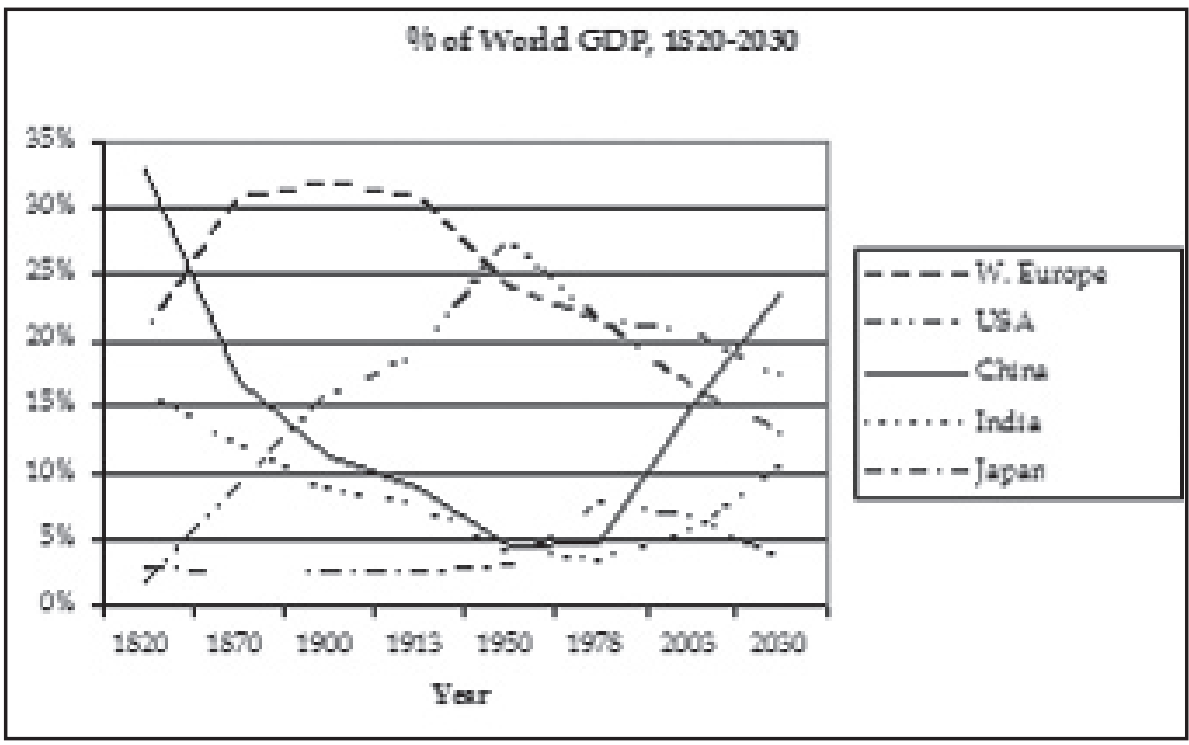

Sources: Maddison 2003, Hu 2005.

Note: Values calculated in Geary-Khamis 1990 international dollars.

combination of industrialization and imperialism (and if that imperialism was an effect of the developmental model of industrial capitalism), one might think that the emergence of China and India could follow the same trends, and that this would cause in the future the same kind of disequilibrium in the world order that had been caused by imperialist powers in the past. This is the logic behind the arguments of analysts who see the emergence of China and India as a threat to the world order. Table 3 summarizes the needs inherent in the developmental model of industrialization, their imperialistic responses and the negative consequences of that dual process.

The emergence of economic and military powers in Western Europe and the United States through industrialization and imperialism throughout the eighteenth and nineteenth centuries established a developmental model that the newly emerging powers of Germany and Japan attempted to follow in the late nineteenth century and the first half of the twentieth century. In each case, the emergence of a new superpower altered the world order and led to war. At the same time, the social transformations provoked by industrialization created underclasses in the metropolis. (In the case of the UK, for instance, enclosure acts to force the urbanization and proletarianization of the rural work-force, colonization of Ireland and restriction of Irish industrialization to com- 
TABLE 3: The Needs of Industrialization and Imperialist Responses

\begin{tabular}{|l|l|}
\hline Industrial needs: & Imperialist responses: \\
\hline - access to raw materials & - captive colonial raw materials \\
- access to energy resources & - captive colonial energy resources \\
- industrial work-force & - captive colonial markets \\
- social transformations: urbanization, & - cheap colonial work-force \\
consumerism & social transformations: conquest \& \\
\hline Traumatic domestic consequences: & Traumatic colonial consequences: \\
\hline - social upheaval & - social upheaval \\
- obsolescence of rural lifestyles & - obsolescence of indigenous cultures \\
- urbanization of the population & - racism \& classism \\
- creation of a proletariat & - exploitation of indigenous peoples \\
- elimination of nomadic lifestyles & - elimination of nomadic lifestyles \\
- consumerism & - consumerism \\
- environmental degradation & - environmental degradation \\
\hline
\end{tabular}

pensate for the destruction of the English agricultural base at the cost of both Anglo-Irish landlords and the indigenous population, the Great Famine, colonization of North America and the Caribbean to guarantee access to raw materials and markets at the cost of the English colonists and indigenous peoples, slavery for sugar and cotton plantations, urban poverty in England, etc.)

In the post-colonial context, some of the paradigms that have served so far to define and analyze this problematic must be deconstructed (Golden 2004, 2005, 2006, 2010). The paradigm that has marked US and NATO geostrategic theories has been the Cold War, the containment of communism, seen as a major threat to the common heritage of the Euro-American 'Enlightenment'. With the fall of the Berlin Wall and the disintegration of the former Soviet Union, there was no communism left to contain, and this threat to the common heritage had been 'overcome'. Even so, the paradigm of containment of a clearly defined enemy persists, and part of the transatlantic geo-political analysis establishment would like to see in the (re)emergence of China an enemy of this kind.

The paradigm of Cold War/post-Cold War Realpolitik represents a vision based on a relatively short period of modern history, a view that prioritizes the self-interest of the former imperial powers. Another paradigm used to analyze the current geo-political situation is the paradigm of post-colonialism, which is part of a historical process of longer duration, beginning with colonialism and passing through decolonization and its consequences. From the perspective of this sec- 
TABLE 4: Consequences for the World Order of the Emergence of New Superpowers

\begin{tabular}{|c|c|}
\hline ializing Nation & Alteration of the World Order: \\
\hline $\begin{array}{l}\text { - Germany (after unification in } \\
\text { 1871) } \\
\text { - Japan (after the Meiji Restoration } \\
\text { in 1868) } \\
\text { - Russia / USSR (19th century; } \\
\text { 1917 Soviet Revolution) } \\
\text { - China (Maoist period, 1949-1976; } \\
\text { Dengist period, } 1978 \text { to date) }\end{array}$ & $\begin{array}{l}\text { - British imperialism; conquests in Ireland, } \\
\text { the Americas, Africa \& Asia; Opium Wars; } \\
\text { Pax Britannica; two world wars; colonial } \\
\text { conflicts; NATO; Cold War } \\
\text { - American imperialism; purchase of } \\
\text { Louisiana \& Alaska; Mexican War (expro- } \\
\text { priation of Texas, Arizona, New Mexico } \\
\text { \& California); conquest and settlement of } \\
\text { North America (genocide of indigenous } \\
\text { peoples); Spanish-American War (expro- } \\
\text { priation of Cuba \& the Philippines); two } \\
\text { world wars; Pax Americana; NATO; Cold } \\
\text { War; hot wars (Korea, Vietnam, Latin } \\
\text { America, Persian Gulf, Afghanistan, Iraq) } \\
\text { - German imperialism; two world wars; } \\
\text { Cold War } \\
\text { - Japanese imperialism; 'Greater East Asia } \\
\text { Co-Prosperity Sphere'; Pacific War; Cold } \\
\text { War } \\
\text { - Russian-Soviet imperialism; Warsaw Pact; } \\
\text { Cold War } \\
\text { - Civil war; Korean War; conflicts with } \\
\text { India, USSR, Vietnam; mass political } \\
\text { campaigns; 'Cultural Revolution'; threat?; } \\
\text { new imperialism?; 'pacific rise'?; 'pacific } \\
\text { development'?; 'harmonious world'? }\end{array}$ \\
\hline
\end{tabular}

ond paradigm, the Cold War is part of the imperialist process: colonialism/neocolonialism. But there is another crucial differentiating factor: post-colonialism prioritizes the interests of the former colonies over former colonial interests. Thus, from the former colonies' perspective the post-colonial paradigm perceives both les droits de l'homme and laissez-faire to be products of a single, asymmetrical process that favoured the former metropolis over the former colonies. A major consequence of this process is a critical post-colonial analysis that includes the deconstruction of Euro-American paradigms and theoretical frameworks to reveal their basis in self-interest. The paradigms of Realpolitik and post-colonialism are incompatible.

A third paradigm that is used to situate this debate is the concept of modernity as the process of consolidating modern science and technology, free market capitalism and liberal democracy as the models for economic and political modernization. In this context, modernity continues to be a product of the Euro-American Enlightenment. If mo- 
dernity is the term used to describe and define an era and a historical process that have been consolidated and have therefore come to an end, a question arises: what could or should come afterwards? If the following period does not represent any change from the previous period, then it would simply be a continuation of it, but if it differs from the previous period, this post-modernity would have to represent a model that is distinct from and alternative to modernity. Thus, for theorists of post-modernity, modernity cannot serve as a model for the modernization of the former colonies, nor should it be maintained in the more developed societies. Post-modernism is a critique of modernity, as much from the viewpoint of the underclasses marginalized by the capitalist developmental model in the former metropolis as from the point of view of peoples who were colonized by imperialism, which was part and parcel of the same model. In this context, the Chinese response to analyses that judge China's (re)emergence to be a threat has been the theory of 和平崛起 heping jueqi ('peaceful rise') or 和平 發展 heping fazhan ('peaceful development'), based on the historical circumstances of the Chinese past, not on the circumstances of the Euro-American past (Zheng 2005; Kang 2005; for a contrasting point of view, see Wade 2004).

\section{Economies of Scale and Comparisons of China}

In absolute terms of GDP, China is now the world's second largest economic superpower. However, in terms of GDP per capita, China is one of the world's poorest countries, at the same level as Angola or the Congo. The situation is paradoxical and unprecedented: China is both an economic superpower and a poor developing nation (Figure 2).

According to the Spanish government, in a ranking based on nationstates, and in absolute terms, Spain is the eighth largest economy in the world. However, it does not seem logical to compare the economic situation of a country like Spain, with a population of 46 million people, with a country like China, which has a population of more than 1,300 million people. Other distortions arise in this kind of comparison: if the US state of California, with a population of 37 million people, were an independent country, it would be the seventh economic power in the world, ahead of Spain. Analyses based on the category of nation-states do not appear to be adequate for the situation of a global economy characterized by a number of trends and processes of regionalization and/or regionalism (Spoor \& Golden 2006), as shown in Table 5. 
FIGURE 2: Total GDP and GDP per Capita (2007)

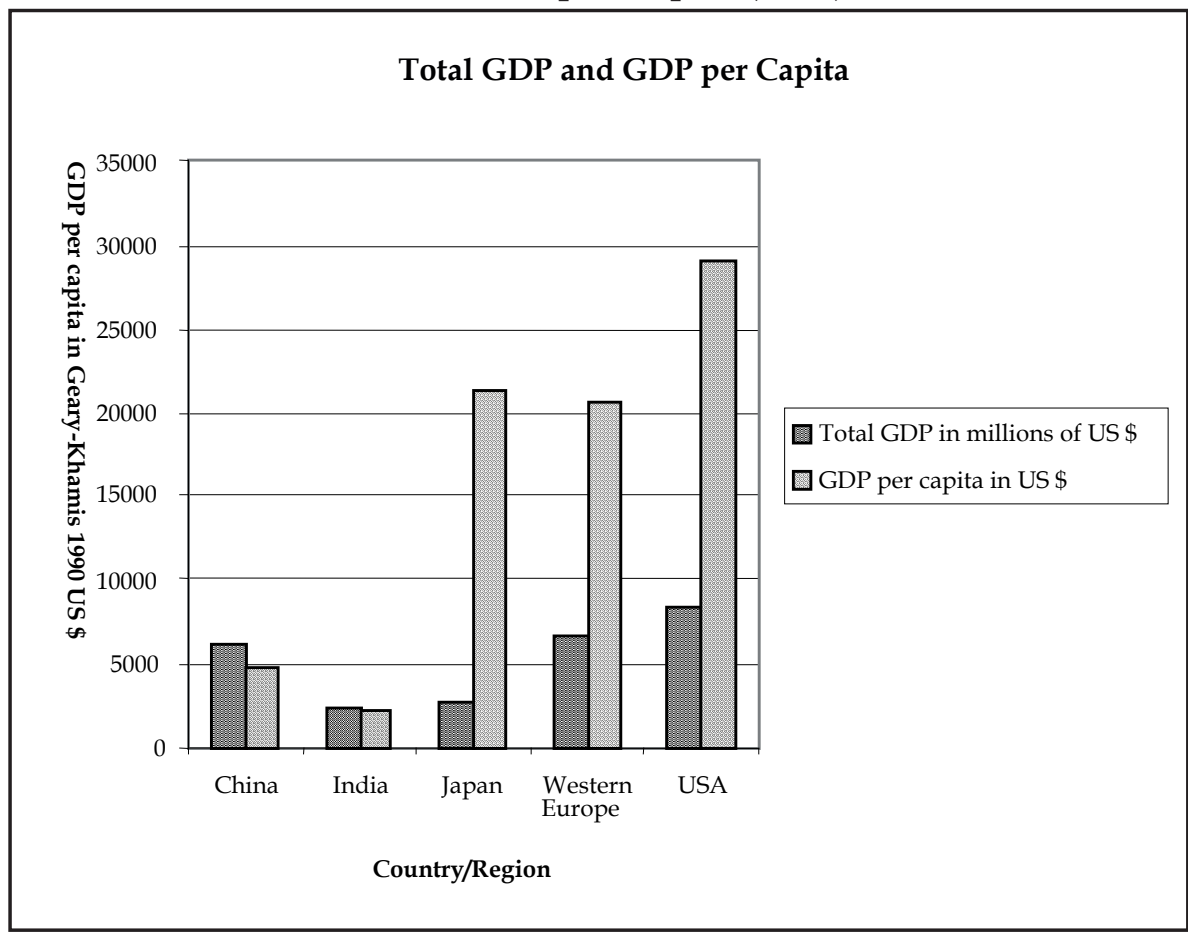

Source: Maddison 2007.

Note: Calculated in Geary-Khamis 1990 international dollars.

TABLE 5: Classification of Countries and Regions by Population and Wealth, 2007

\begin{tabular}{|l|c|c|c|}
\hline \multicolumn{1}{|c|}{ Country/Region } & $\begin{array}{c}\text { Population } \\
\text { (in millions) }\end{array}$ & $\begin{array}{c}\text { \% World } \\
\text { Population }\end{array}$ & $\begin{array}{c}\text { \% World } \\
\text { GDP }\end{array}$ \\
\hline China & 1,300 & 20.71 & 15.12 \\
\hline India & 1,100 & 17.52 & 5.54 \\
\hline ASEAN & 550 & 8.76 & 4.91 \\
\hline EU 27 & 500 & 7.96 & 20.61 \\
\hline USA & 300 & 4.78 & 20.26 \\
\hline MERCOSUR & 260 & 4.14 & 3.30 \\
\hline Indonesia & 230 & 3.66 & 1.86 \\
\hline Brazil & 190 & 3.03 & 2.48 \\
\hline Russia & 145 & 2.31 & 2.23 \\
\hline Japan & 127 & 2.02 & 6.60 \\
\hline Spain & 40 & 0.64 & 1.67 \\
\hline California & 37 & 0.59 & 2.68 \\
\hline
\end{tabular}

Source: Maddison 2007.

Note: California GDP is estimated as 13 per cent of US GDP. 
FIGURE 3: Relationship between Population and World GDP (2007, in per cent)

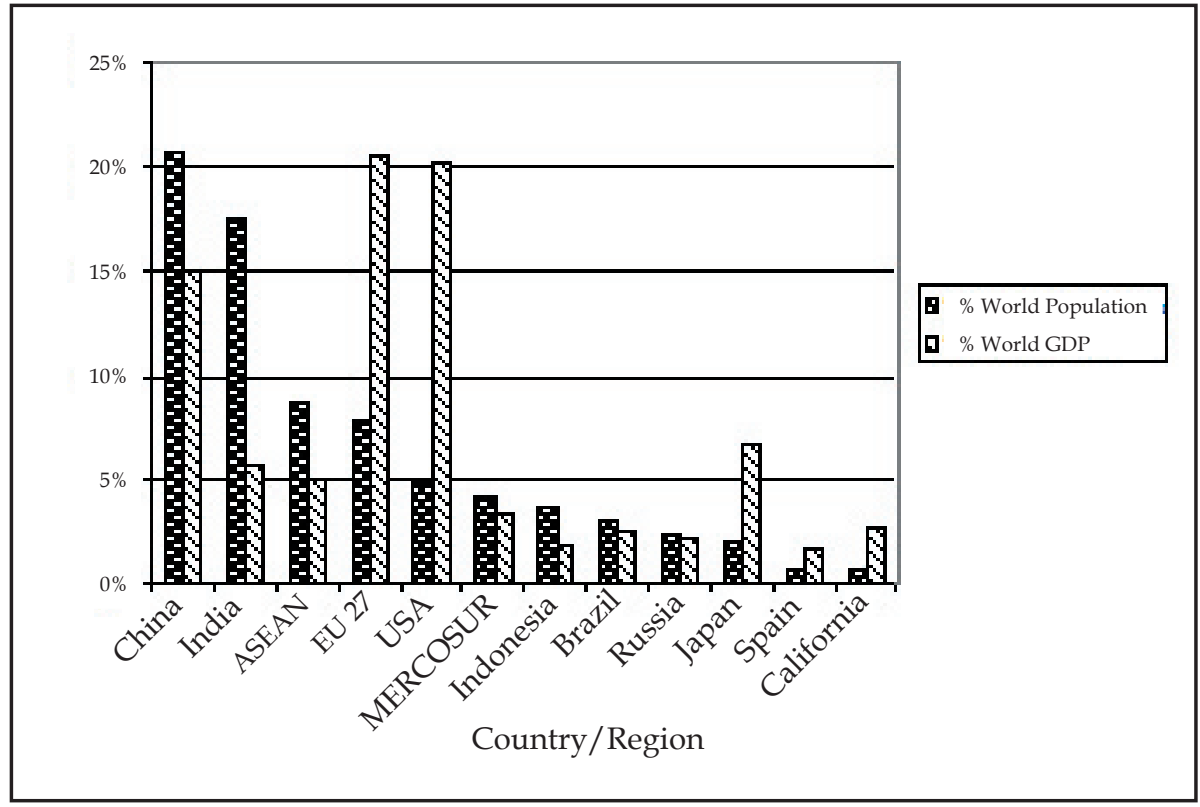

Source: Maddison 2007.

Note: California GDP is estimated as 13 per cent of US GDP.

In the Euro-American historical circumstances, the nation-state as a political entity defined itself by opposition to the empires of Europe, which were by nature much larger in terms of territory and population, as well as being multinational, multicultural, multilingual and multireligious, completely the opposite of the emerging nation-states. According to this Euro-American perspective, the European empires were obsolete and the nation-states modern. The emergence of nation-states involved the disintegration of empires such as the Austro-Hungarian (although some of these same emerging nation-states would create and try to maintain their own overseas empires). Compared with the continent of Europe, the Chinese empire never disintegrated permanently into many independent nation-states. Moreover, regionalization processes tend to (re)create supranational entities, and in the case of Asia, in circumstances very different from those of Europe and the Americas (Cooper 2000; Andersen 2006; Wang 2007).

The terminology of Chinese political scientists distinguishes between a 帝国 diguo ('empire'; 帝 di 'emperor' plus 国 guo 'country') and a 国家 guojia ('nation-state'; 国 guo 'country' plus 家 jia 'family'), but it can also describe the nature of supranational entities such as the European Union as a process of creating a 帝国型国家 diguo xing guojia or 'nation-state 
with the characteristics of an empire', precisely because it is large in terms of territory and population, as well as being multinational, multicultural, multilingual and multireligious (like China), In this context, the question can arise as to whether the nation-state is the right model for China, or whether the Chinese empire was historically and qualitatively different from European empires and whether there are aspects of the administration of the Chinese empire that are still relevant to the administration of the People's Republic (Wang 2007). In addition, the Chinese case may be defined as a 國黨 guodang ('party-state') as a result of the non-separation of powers between the Communist Party and the state administration or the civil service (in many respects a similar situation to the confusion between the powers of the Roman Catholic Church and the emerging European nation-states before the separation of church and state in the Euro-American ambit).

In addition, Chinese analysts distinguish between a 大國 daguo ('large country'), a 超級大國 chaojidaguo ('superpower') and a 負責國 fuzeguo ('a country with geo-political responsibilities'). China is a large developing country (daguo), the third largest country in the world in terms of territory after Russia and Canada, with the largest population in the world, and this factor of scale greatly complicates its administration and search for suitable models to modernize and democratize the state administration. China shuns the status of a hegemonic superpower (chaojidaguo) but has begun to accept its status as a country with responsibilities (fuzeguo), which should assume a geo-political weight in the world that would correspond to its global economic weight (Hu 2005a, 2005b; Qin 2005; Voskressenski 2005).

If we compare the situation in China with the status of the European Union as a whole, not with individual countries such as Spain, France, Germany or the UK, then the problems that arise in an EU context take on a new perspective and are more similar to China's problems: territorial cohesion, ethnic conflicts, religious conflicts, a democratic deficit, economic inequalities, domestic migration, a failed state (Northern Ireland), a divided country (Cyprus), nations without states, experiences of transition from Fascist and Soviet dictatorships to democracy, modernization of the economy, reform of the labour market, a monetary union. In this regard it is interesting to note the need experienced by the European Union, as part of its supranational evolution, to create a fourth estate of power, in addition to the executive, legislative and judicial branches of traditional liberal democracy: the European Commission, a governing body made up of technocrats who are selected rather than 
elected, to formulate policies and ensure continuity. In many ways it resembles the 'mandarinate', the bureaucracy of technocrats that the Chinese empire felt the need to create and maintain more than two millennia ago. It would appear that a supranational entity like the EU needs additional organs, distinct from the executive, legislative and judiciary that characterize the nation-state of liberal democracy. In the case of the People's Republic, a bureaucracy of technocrats has been maintained but the executive, legislative and judicial branches of government have not (yet) been separated.

\section{The Perception of Risk from a Chinese Perspective}

In his proposal for a 中國大戰略 Zhongguo da zhanlue ('Grand Strategy for China'), the economist 胡鞍钢 Hu Angang summarizes the importance of China's peaceful (re)emergence by saying that the fact that the Chinese people, with a population of more than one billion, should become a moderately prosperous society [小康社会 xiaokang shehui] is of great importance in the history of human development. He calculates the population of the highest-income countries as less than 900 million, but says it cost them more than 200 years to reach today's level, counting from the period of the industrial revolution. The population of countries with medium incomes is less than 600 million, but they took about 100 years to reach today's level, from the beginning of the twentieth century. The combined populations of these two types of countries is 1,470 million, representing $25 \%$ of the world's total. Hu states that China, in just 100 years, the period from 1950 to 2050, will have brought its population of between 1,500 million and 1,600 million people, to the level of moderately developed countries, creating a miracle of human development (Hu 2003).

The party-state's capacity to perform this transformation, maintaining institutional stability and a sustained rate of economic growth (efficiency), and equitably distributing wealth (equity) is the factor that gives it political legitimacy. Therefore, there are three key elements for the country's future: stability, efficiency and equity. The risk aversion that characterizes China's traditional culture helps in maintaining stability, but any event or process that could interfere with efficiency or equity, or the sum of various destabilizing factors, could precipitate a crisis in the People's Republic. For this reason, the party-state and its advisors are dedicated to the analysis of risk factors that could become threats or risks, and to developing risk management strategies. Table 
TABLE 6: The Perception of Risk from a Chinese Perspective

\begin{tabular}{|c|c|}
\hline risks: & al risks: \\
\hline $\begin{array}{l}\text { - centrifugal socio-economic forces } \\
\text { - uneven regional development } \\
\text { - rural-urban divide } \\
\text { - urbanization of a rural population (risk } \\
\text { of Latin Americanization) } \\
\text { - shortage of resources (raw materials, } \\
\text { energy) } \\
\text { - environmental degradation ('green' } \\
\text { GDP) } \\
\text { - corruption ('white' GDP) } \\
\text { - social welfare (aging, education, health, } \\
\text { unemployment) } \\
\text { - consolidation of a domestic consumer } \\
\text { market } \\
\text { - climate change, natural disasters } \\
\text { - epidemics } \\
\text { - organized crime } \\
\text { - ethnic conflict } \\
\text { - nationalism } \\
\text { - populism } \\
\text { - democratization of a large country } \\
\text { (daguo) }\end{array}$ & 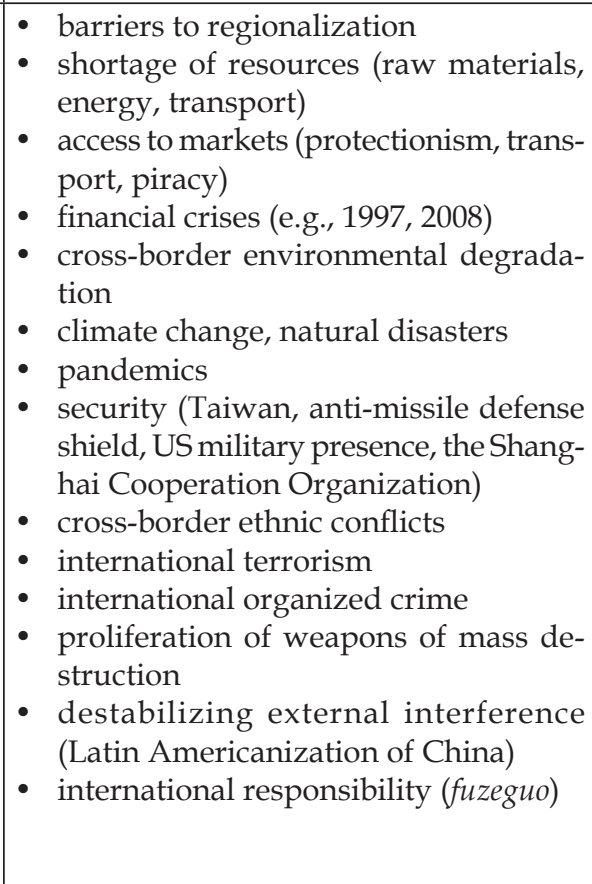 \\
\hline
\end{tabular}

6 summarizes the kind of domestic or international risks that threaten the policy described by $\mathrm{Hu}$ Angang.

Domestically, uneven economic development generates centrifugal socio-economic forces. The inequalities of development between coastal regions and the hinterland and between the countryside and cities create a huge 'floating' population of cheap and unskilled labour that migrates to the cities to find work. But the cities cannot absorb the domestic migrant population. The privatization of formerly state-owned enterprises generates unemployment in a context that does not include the guarantees or support of a welfare state. Some economists such as 温铁军 Wen Tiejun warn that the sudden urbanization of the rural population carries the risk of a 'Latin Americanization' of the country. They have studied the results of this process in Latin America and identified the social and economic risks (poverty, marginalization, crime) that accompany the creation of slums (favelas) and hinder the economic growth of a developing country (Wen 2005). In this sense, any problem that interferes with the sustained development of China's economy is a threat to stability. China suffers a shortage of natural resources, both raw materials and energy resources (except highly polluting coal), which are essential for 
industrialization. At the same time, industrialization leads to serious environmental degradation, in addition to the effects of climate change and natural disasters, which Chinese economists define as a 'green' GDP that takes into account the negative effects of environmental degradation on development. Another negative factor for development is corruption, which they call the 'white' GDP. The social costs of development and the need to create a network of social welfare for a population that has begun to age are very high. The engine of recent Chinese growth has been exports, but the only guarantee of economic stability for the future is the consolidation of a domestic consumer market, a return to the kind of self-sufficient economy that made the Chinese empire strong until the nineteenth century. Medical problems such as SARS or avian influenza have highlighted the potential economic costs of epidemics. Organized crime has returned and represents a significant cost, as do ethnic conflicts and separatism.

Its ability to manage these risks is what determines the legitimacy of the party-state. There is no separation between the party and the administration or the public service in the People's Republic, a situation that hinders any possibility of alternation in power in the short to medium term. Still, the possibility of a loss of legitimacy because of the mismanagement of any of these risks - or the sum of various risks - could precipitate social movements that could alter the political status quo. In this case, populist nationalism could become a viscerally attractive force capable of ousting the Chinese Communist Party. For some advisers, such as 俞可平 Yu Keping, the political management of these risks requires the maintenance of sustained but also sustainable economic growth, and an equitable redistribution of wealth, accompanied by political reform-democratization - that should take place in a gradual and balanced way in accordance with the circumstances of a very large country (daguo) (Yu 2009).

Internationally, there are several factors that could destabilize the party-state of the People's Republic. The regionalization of East Asia and Southeast Asia (ASEAN +3, ASEAN +6, the East Asia Summit) and the creation of a monetary union (the 'Asian dollar') in order to withstand financial crises (as in 1997) are self-defense strategies of great interest to China in a global economy. Any obstacle to regionalization, such as the reluctance of Japan or US interference, could threaten this process. The scarcity of natural resources essential for industrialization forces China to compete for them on an increasingly more expensive international market. Any hindrance to China's access to raw materials or energy 
sources would lead to risk. The same goes for access to markets as a result of protectionist policies or interference with transport (for this reason China is actively involved in the control of piracy and preoccupied by the presence of the US Seventh Fleet in the waters Chinese cargo ships must navigate). Environmental degradation crosses borders, as do the effects of climate change, natural disasters and pandemics.

In the security field, China feels an urgent need to defend its sovereignty and territorial integrity. The 'unequal treaties' of the imperialist era, which in China is called the 百年国耻 bainian guochi, 'century of humiliation', imposed extraterritoriality and stripped sovereignty from the Chinese empire. The nation-states that justified their incursions into China based on their own sovereignty did not recognize Chinese sovereignty. To deal with these former aggressors on an equal footing, China must demonstrate its ability to consolidate and defend its own territorial integrity, which implies, in part, the recovery of land expropriated by imperialism (Taiwan) and the repression of separatist movements (Tibet, Xinjiang). China sees another threat in the United States's military presence in the Asia-Pacific region (the Seventh Fleet, the proposed missile shield that excludes China, covert support to Taiwan), or in Central Asia, which could also interfere with China's commercial trade or the transportation of raw materials and energy sources. For this reason, China promotes the consolidation of the Shanghai Cooperation Organization (SCO) as a counterweight to US strategies and/ or NATO, and as a factor promoting geo-political multipolarity. China shares borders and ethnic groups with several countries where transnational trends carry the risk of separatist movements across national borders, a phenomenon parallel to the dangers of international terrorism, the proliferation of weapons and weapons of mass destruction, and international organized crime. In various fields, Chinese advisers perceive the possibility of destabilizing interference promoted by foreign powers (such as the Latin Americanization of China), while fearing that demands from the UN, the US or the EU that China assume a responsibility in international politics (fuzeguo) proportional to its global economic weight, could force China to give its approval to interference in the internal affairs of sovereign states. If China accepted the possibility of such interference, it could itself become subject to interference in the case of a possible intervention in Taiwan, something that China considers to be a domestic matter, a matter of its own sovereignty and territorial integrity. In addition, if China participates in international intervention policies, it could be exposed to military losses and terrorist reprisals. 


\section{Case Studies of the Perception of Risk from a Chinese Perspective}

The following analysis of risks (Table 7) that threaten the sustainability of Chinese growth made by the RAND Corporation, a US think-tank, helps to highlight the distinctions between the Chinese perception of risk and the Euro-American perception.

TABLE 7: RAND Corporation Analysis of Risks for the Sustainability of Chinese Growth

\begin{tabular}{|c|c|}
\hline Risk factors & $\begin{array}{l}\text { Cost } \\
\text { (negative } \\
\text { GDP) }\end{array}$ \\
\hline \multicolumn{2}{|l|}{ 1. Institutional } \\
\hline $\begin{array}{l}\text { - official and unofficial unemployed, poverty and social instability } \\
\text { due to structural reforms as a result of entering the WTO, unequal } \\
\text { distribution of income }\end{array}$ & $3.0 \%-6.0 \%$ \\
\hline - various kinds of corruption ('white' GDP) & $5.0 \%$ \\
\hline \multicolumn{2}{|l|}{ 2. Sectorial } \\
\hline - epidemics & $1.8 \%-2.2 \%$ \\
\hline $\begin{array}{l}\text { - shortage of water resources in northern China, worsening environ- } \\
\text { mental degradation, diversion of water from some southern rivers } \\
\text { to the north ('green' GDP) }\end{array}$ & $1.0 \%-2.0 \%$ \\
\hline - declining supply of energy resources on a worldwide level & $1.0 \%$ \\
\hline \multicolumn{2}{|l|}{ 3. Financial } \\
\hline $\begin{array}{l}\text { - nonperforming loans (NPLs), capital flight, debts unpaid by state- } \\
\text { owned enterprises }\end{array}$ & $0.9 \%-1.3 \%$ \\
\hline - reduction of foreign direct investment (FDI) & $0.8 \%-1.6 \%$ \\
\hline \multicolumn{2}{|l|}{ 4. Conflicts } \\
\hline $\begin{array}{l}\text { - Taiwan, Korean Peninsula, India, Pakistan, other factors of uncer- } \\
\text { tainty }\end{array}$ & $1.0 \%-1.3 \%$ \\
\hline Potential economic loss of GDP according to RAND & $14.5-18.4 \%$ \\
\hline
\end{tabular}

Source: $\mathrm{Hu} 2003$.

Hu Angang (2003) said that RAND researchers had noted in their report that even if only one of these eight factors occurred at any given time, China's economy would be seriously affected. In his own analysis, Hu used somewhat different factors and weighted them differently as well, with even more critical results (Table 8).

This analysis of risks for the sustainability of Chinese growth offers pessimistic scenarios much worse than those described by the RAND analysts, partly because $\mathrm{Hu}$ tries to quantify the costs of environmental degradation ('green' GDP) and corruption ('white' GDP), which is an exercise Euro-American economists shun, and also because Chinese analysts may have better access to more relevant and reliable statistics. 
TABLE 8: Hu Angang's Analysis of Risks for the Sustainability of Chinese Growth

\begin{tabular}{|l|c|}
\hline Risk factors & $\begin{array}{c}\text { Cost } \\
\text { (negative } \\
\text { GDP) }\end{array}$ \\
\hline $\begin{array}{l}\text { - a high rate of unemployment represents mismanagement and } \\
\text { waste of the work-force }\end{array}$ & $7.0 \%-8.0 \%$ \\
\hline $\begin{array}{l}\text { - the influence of various kinds of corruption and monopoly ('white' } \\
\text { GDP) }\end{array}$ & $14.0 \%-15.0 \%$ \\
\hline - economic losses caused by various kinds of natural disaster & $3.0 \%-5.0 \%$ \\
\hline $\begin{array}{l}\text { - shortage of water resources in northern China, worsening pollu- } \\
\text { tion, project transferring water from some rivers south to north } \\
\text { ('green' GDP) }\end{array}$ & $1.0 \%-2.0 \%$ \\
\hline - the loss of natural resources & $4.5 \%$ \\
\hline $\begin{array}{l}\text { - the production and sale of adulterated, counterfeit and substand- } \\
\text { ard quality goods, violation of intellectual property rights and } \\
\text { piracy }\end{array}$ & $2.0 \%-3.0 \%$ \\
\hline - reduction of foreign direct investment (FDI) & $0.8 \%-1.6 \%$ \\
\hline Potential economic loss of GDP according to Hu Angang & $\mathbf{3 0 . 5} \% \mathbf{- 3 5 . 5 \%}$ \\
\hline
\end{tabular}

Source: $\mathrm{Hu} 2003$

In any case, it suggests that Chinese leaders design their strategies for managing risks to the sustainability of Chinese growth - and therefore their own political survival - with better knowledge and a more realistic approach than do foreign analysts.

\section{China's Comprehensive National Power (CNP) in Comparison with Other Countries}

Perhaps the most emblematic example of the contemporary Chinese perception of risk is the development of the concept of 综合国力 zonghe guoli or comprehensive national power (CNP), which many Chinese analysts consider the most important Chinese contribution to international relations theory (Wang 1996; Pillsbury 2000; Hu \& Men 2002; Kang 2005; Anguiano 2008; Lampton 2008; Leonard 2008).

The Department of Defence of the United States differentiates a few elements of China's politico-military strategy.... On the military front they are aware of the 'Grand Strategy' project that China's leaders defined as 'the overall strategy of a nation or alliance of nations which brings into play the whole of the nation's strength' to achieve political goals, especially those related to national security and development. ... There are two key issues in the Chinese conception of how to achieve this balance of priorities: the idea of 'comprehensive national power' (CNP) and the 'strategic configuration of power' or [勢] shi. CNP is how China's strategists evaluate and measure national power in their own country, in comparison with that of others, 
including the quantitative and qualitative extent of territory, natural resources, economic power, diplomatic influence, military capabilities and cultural influence.... The 'strategic configuration of power' - shi-is roughly equivalent to the concept of the foreign 'alignment of forces' whose challenges, threats and opportunities must be properly assessed in order to readjust the national strategy (Anguiano 2008: 60-61).

Michael Pillsbury analyzed the origins and development of the contemporary Chinese concept of comprehensive national power in great detail (Pillsbury 2000). He cites 吴春秋 Wu Chunqiu of the Academy of Military Science of the People's Liberation Army (PLA AMS) (军事科学研究院 Junshi Kexue Yan Jiu Yuan), who attributes to ancient Chinese military strategists an early version of CNP: 'China's wise ancient strategists never advocated relying only on military power to conquer the enemy, but emphasized combining military power with the nonmilitary power related to war in order to get the upper hand' (Pillsbury 1991: 107-108). Wu cites Sunzi's 'five things' and 'seven stratagems' that governed the outcome of war, and says that pondering these components, which include politics, military affairs, economics, geography, and 'subjective guidance', could forecast the results of a war in advance. The Art of War by 吳子 Wuzi defines six conditions under which war should be avoided if the other side's strength was greater, including the factors of national territory, population, domestic embodiment power, the legal system, servants, the quantity and quality of troops, as well as international aid. Wu concludes that even in an assessment based on modern views, these factors are relatively complete and are the epitome of comprehensive national power, as are the 'eight views' discussed by 管子Guanzi that show the size, strength, and development of a country's national power (Pillsbury 1999; cf. Pillsbury 2000; Wu 1995: 98; Huang 1992).

Pillsbury also cites 黄硕风 Huang Shuofeng of the PLA AMS, who said that Deng Xiaoping asked Chinese scholars in 1984 to analyze the future security environment, as part of a study on China's national defense strategy for the year 2000. Huang describes CNP as a complex system composed of four major index subsystems - the material power (hard) index subsystem, the spirit power (soft) index subsystem, the coordinated power index subsystem, and the environmental index subsystem. The material power and spirit power indexes reflect the strength a country needs for survival and development; the coordinated power index reflects the leadership's organization, command, management, and decision-making levels; and the environmental index reflects the restricting conditions of comprehensive national power. Material power 
TABLE 9: People's Liberation Army Academy of Military Science (PLA AMS) Subsystems and Subindices of Comprehensive National Power

\begin{tabular}{|c|c|}
\hline Subsystem & Subindex \\
\hline Political power & $\begin{array}{l}\text { - } \text { national strategy goals } \\
\text { - political stability } \\
\text { - policy level } \\
\text { - the nation's leadership, organization, and decision-making } \\
\text { capability } \\
\text { - national embodiment power }\end{array}$ \\
\hline Foreign affairs power & $\begin{array}{l}\text { - foreign political relations } \\
\text { - foreign economic relations } \\
\text { - foreign military relations } \\
\text { - diplomatic activities capability } \\
\text { - international contribution capability }\end{array}$ \\
\hline $\begin{array}{l}\text { Science and technology } \\
\text { power }\end{array}$ & $\begin{array}{l}\text { - science and technology troops (scientists and engineers, techno- } \\
\text { logical personnel) } \\
\text { - investment in science and technology (total, proportion of the } \\
\text { GNP) } \\
\text { - science and technology level (high science and technology, } \\
\text { general science and technology) } \\
\text { - science and technology system } \\
\text { - scientific and technological progress speed } \\
\text { - scientific and technological progress contribution } \\
\text { - scientific and technological results and applications }\end{array}$ \\
\hline National defense power & $\begin{array}{l}\text { - standing army (nuclear, conventional) and reserve forces } \\
\text { - national defense investment } \\
\text { - national defense science and technology and national defense } \\
\text { industry } \\
\text { - national defense bases and installations } \\
\text { - strategic material reserves and logistics safeguards } \\
\text { - national defense education and training } \\
\text { - national defense system establishment } \\
\text { - national defense ideology of the people and troop morale }\end{array}$ \\
\hline
\end{tabular}

Sources: Pillsbury 2000, Huang 1992.

includes hard factors (natural resources, economics, science and technology, and national defense) and some soft factors (national defense ideology and military theory). Spiritual and intellect power includes soft factors (politics, foreign affairs and culture and education). For each of these sub-subindices, Huang provides detailed lists of their contents, but only four of Huang's lists are seen here for comparison, two from the soft factor side, and two from the hard factor side (Table 9) (Pillsbury 2000; cf. Huang 1992): 
TABLE 10: Categories and Indicators of CNP

\begin{tabular}{|c|c|}
\hline Categories & Indicators \\
\hline \multirow[t]{2}{*}{ Economic resources } & - $\quad$ GDP in PPP \\
\hline & - $\quad \%$ World GDP \\
\hline \multirow[t]{2}{*}{ Human capital } & - $\quad \%$ of $15-64$ year old people in the world's total \\
\hline & - $\quad$ average years of schooling \\
\hline \multirow[t]{4}{*}{ Natural resources } & - electricity production \\
\hline & - commercial energy use \\
\hline & - $\quad$ arable land \\
\hline & - $\quad$ freshwater withdrawals \\
\hline \multirow[t]{3}{*}{ Capital resources } & - Gross Domestic Investment \\
\hline & - Capital market value \\
\hline & - net FDI \\
\hline \multirow{5}{*}{$\begin{array}{l}\text { Knowledge \& technological re- } \\
\text { sources }\end{array}$} & - $\quad$ personal computers \\
\hline & - patent applications filed by residents \\
\hline & - $\quad$ scientific \& technical journal articles \\
\hline & - internet hosts \\
\hline & - $\quad$ R\&D spending \\
\hline \multirow[t]{2}{*}{ Governmental resources } & - $\quad \%$ of central spending in GDP \\
\hline & - $\quad \%$ of central spending in world's total \\
\hline \multirow[t]{2}{*}{ Military resources } & - $\quad$ armed forces personnel \\
\hline & - military expenditures \\
\hline \multirow[t]{3}{*}{ International resources } & - $\quad$ exports \& service \\
\hline & - $\quad$ imports and service \\
\hline & - $\quad$ royalty and license fees receipts \\
\hline
\end{tabular}

Sources: Hu \& Men 2002; Porter 1992, 2000.

There are several Chinese think-tanks involved in the calculation of comprehensive national power through various and differing combinations of statistical indicators. Hu Angang 胡鞍钢 and Men Honghua 门 洪华 attribute the concept explicitly to 孫子兵法 Sunzi bingfa, and quote the beginning of that text with the same five factors discussed earlier in this study:

The art of war is of vital importance to the State. It is a matter of life and death, a road either to safety or to ruin. Hence it is a subject of inquiry which can on no account be neglected. The art of war, then, is governed by five constant factors, to be taken into account in one's deliberations, when seeking to determine the conditions obtained in the field. These are: (1) The Moral Law; (2) Heaven; (3) Earth; (4) The Commander; (5) Method and discipline (Hu \& Men 2002: 1).

For $\mathrm{Hu}$ and Men, CNP means 'the sum total of the powers or strengths of a country in economy, military affairs, science and technology, education and resources and its influence'. It combines all the powers possessed 
by a country for the survival and development of a sovereign state, 'including material and ideational ethos, and international influence'. It measures the basic national conditions and resources of a country, and the economic, political, military and technical powers of a country. CNP stresses comprehensiveness and all aspects, 'including material strength, ideational ethos and international influence' (Hu \& Men 2002: 2).

CNP may be simply defined as the comprehensive capabilities of a country to pursue its strategic objectives by taking actions internationally and the core factors to the concept are strategic resources, strategic capabilities and strategic outcomes, with the strategic resources as the material base (Hu \& Men 2002: 3).

Although their study concentrates on 'hard power' elements of CNP, they also stress the importance of 'soft power' elements, including culture (since then the Chinese government has also launched more than 300 'Confucius Institutes' in more than 90 countries as part of its overall CNP strategy). On the basis of Michael Porter's categories of physical resources, human resources, infrastructure, knowledge resources and capital resources, they divided national strategic resources into eight categories, with 23 indicators, in order to calculate CNP (Table 10).

Their application of these categories and indicators to an analysis of the comparative CNP of five major powers produced the following result (Table 11). On the basis of this comparative analysis, Hu and Men offered the following example of a comprehensive national power ranking among some of the world powers (Table 12). Michael Pillsbury also detailed the categories and indicators used by the Chinese Academy of Social Sciences (中国社会科学院 Zhongguo Shehui Kexueyuan), which are outlined in Table 13. The differing choice of categories and indicators, as well as differing systems of weighting them, produce different results in the overall rankings. Pillsbury attributes part of the difference to the 'military' nature of the PLA AMS approach and the 'civilian' nature of the CASS approach, summarized by Table 14 .

According to Pillsbury, the 'military' approach was consistent with 'the orthodox Chinese view that a multipolar world structure is emerging and that US hegemony is ending', while the 'civilian' approach contradicted 'the orthodox view about an emerging multipolar structure'.

The most striking contrast is the assessment of China's growth rate relative to the United States.... The civilian team does not rank China equal to the United States by 2020 but merely ranks it number [seven] in the world ... Chinese military authors assert that national power scores probably determine the outcome of wars. If so, the Chinese military team's quantitative results suggest China has little to fear from Japanese national power by 2010 
TABLE 11: Strategic Resources and CNP of Five Major Powers (Percentage of World Total)

\begin{tabular}{|c|c|c|c|c|c|c|}
\hline Country & 1980 & 1985 & 1990 & 1995 & 1998 & $\begin{array}{l}\text { Variation } \\
1980-1998\end{array}$ \\
\hline \multicolumn{7}{|c|}{ Economic resources } \\
\hline China & 3.10 & 4.57 & 5.63 & 8.87 & 10.23 & 7.07 \\
\hline India & 3.36 & 3.80 & 4.35 & 5.02 & 5.41 & 2.05 \\
\hline Japan & 8.04 & 8.27 & 8.73 & 8.38 & 7.82 & -0.22 \\
\hline Russia & & & 5.43 & 3.02 & 2.52 & \\
\hline USA & 21.96 & 21.60 & 20.85 & 20.73 & 21.29 & -0.67 \\
\hline Five in total & & & 44.99 & 46.02 & 47.27 & \\
\hline \multicolumn{4}{|c|}{ Human capital } & (1999) & & \\
\hline China & 17.60 & 18.70 & 20.20 & 21.90 & 24.00 & 6.40 \\
\hline India & 8.40 & 9.06 & 9.98 & 11.10 & 12.30 & 3.90 \\
\hline Japan & 4.36 & 4.01 & 3.73 & 3.55 & 3.27 & -1.09 \\
\hline Russia & 5.69 & 5.30 & 5.05 & 4.26 & 4.06 & -1.63 \\
\hline USA & 1.16 & 1.02 & 9.30 & 9.01 & 8.60 & -3.00 \\
\hline Five in total & 47.70 & 47.20 & 48.20 & 49.80 & 52.2 & 0.45 \\
\hline \multicolumn{7}{|c|}{ Natural resources } \\
\hline China & 8.65 & 8.57 & 9.30 & 9.62 & 9.64 & 1.23 \\
\hline India & 6.68 & 6.75 & 6.97 & 6.59 & 6.68 & 0.00 \\
\hline Japan & 3.34 & 3.23 & 3.41 & 3.54 & 3.48 & 0.20 \\
\hline Russia & & & 7.57 & 7.10 & & \\
\hline USA & 18.29 & 16.81 & 16.42 & 15.95 & 16.02 & -2.44 \\
\hline Five in total & & & 43.26 & 42.84 & & \\
\hline \multicolumn{7}{|c|}{ Capital resources } \\
\hline China & 2.21 & 3.81 & 3.87 & 10.00 & 9.40 & 7.19 \\
\hline India & 1.50 & 2.16 & 2.00 & 2.70 & 2.50 & 1.00 \\
\hline Japan & 5.25 & 5.52 & 14.40 & 10.50 & 6.90 & 1.65 \\
\hline Russia & & & 1.50 & 0.90 & & \\
\hline USA & 23.02 & 20.33 & 23.40 & 23.80 & 31.10 & 8.08 \\
\hline Five in total & & 43.67 & 48.50 & 50.80 & & \\
\hline \multicolumn{7}{|c|}{ Knowledge and technological resources } \\
\hline China & 0.79 & 0.94 & 1.01 & 1.34 & 1.85 & 1.06 \\
\hline India & 2.23 & 2.01 & 1.23 & 0.85 & 1.06 & -1.17 \\
\hline Japan & 8.23 & 9.17 & 8.56 & 15.32 & 14.70 & 6.47 \\
\hline Russia & & 0.08 & 1.76 & 1.61 & & \\
\hline USA & 32.69 & 32.80 & 34.26 & 34.59 & 34.93 & 2.24 \\
\hline Five in total & & 45.14 & 53.86 & 54.15 & 10.21 & \\
\hline \multicolumn{7}{|c|}{ Governmental resources } \\
\hline China & 1.84 & 1.48 & 1.16 & 1.03 & 1.15 & -0.69 \\
\hline India & 1.63 & 2.10 & 2.66 & 2.46 & 2.72 & 1.09 \\
\hline Japan & 5.83 & 5.18 & 5.24 & 7.60 & 7.60 & 1.77 \\
\hline Russia & & & 2.60 & 2.60 & & \\
\hline USA & 19.10 & 19.00 & 18.70 & 15.90 & 15.80 & -3.3 \\
\hline Five in total & & & 29.05 & 29.870 & & \\
\hline \multicolumn{7}{|c|}{ Military resources } \\
\hline China & & 8.57 & 7.91 & 7.31 & 7.40 & -1.17 \\
\hline India & & 3.97 & 4.14 & 5.01 & 5.96 & 1.99 \\
\hline Japan & 1.50 & & 1.84 & 2.38 & 2.34 & 0.84 \\
\hline Russia & & & 6.40 & 5.94 & & \\
\hline USA & 21.07 & 21.24 & 21.55 & 19.83 & 21.07 & -1.24 \\
\hline Five in total & & & 42.65 & 41.47 & & \\
\hline \multicolumn{7}{|c|}{ International resources } \\
\hline China & 0.59 & 0.91 & 0.74 & 1.35 & 1.83 & 1.24 \\
\hline India & 0.40 & 0.49 & 0.44 & 0.48 & 0.55 & 0.15 \\
\hline Japan & 7.55 & 9.05 & 9.97 & 10.38 & 8.80 & 1.25 \\
\hline Russia & & & & 0.82 & 0.73 & \\
\hline USA & 22.47 & 24.01 & 22.10 & 22.18 & 24.23 & 1.76 \\
\hline Five in total & & & & 35.21 & 36.14 & \\
\hline
\end{tabular}

Source: Hu \& Men 2002. 
TABLE 12: Hu Angang \& Men Honghua's CNP Index for Five Powers (Percentage of World Total)

\begin{tabular}{|l|l|l|l|l|l|l|l|}
\hline Country & $\mathbf{1 9 8 0}$ & $\mathbf{1 9 8 5}$ & $\mathbf{1 9 9 0}$ & $\mathbf{1 9 9 5}$ & $\mathbf{2 0 0 0}$ & $\mathbf{2 0 0 3}$ & Variation 1980-2003 \\
\hline China & 4.74 & 5.31 & 5.65 & 7.16 & 8.77 & 9.99 & 5.26 \\
\hline India & 3.38 & 3.62 & 3.74 & 4.01 & 4.54 & 4.87 & 1.49 \\
\hline Japan & 6.04 & 6.34 & 7.32 & 8.54 & 7.73 & 7.00 & 0.00 \\
\hline Russia & & & 3.27 & 2.81 & 2.93 & 2.93 & \\
\hline US & 22.49 & 22.02 & 22.14 & 21.90 & 22.52 & 22.27 & -2.21 \\
\hline TOTAL & & & 42.11 & 41.61 & 46.48 & 47.07 & \\
\hline
\end{tabular}

Sources: Hu \& Men 2002, updated in 2007 by Hu Angang (cf. Lampton 2008: 23).

and still less by 2020 when Japan will slip to fourth place. Better still, in terms of military threats to China, the military team's results suggest China will have three-fourths of the power score of the United States by 2010 and become co-equal to the United States by 2020 (Pillsbury 2000).

A.I. Johnston compared Pillsbury's analysis of the PLA AMS and CASS results to those of the China Institute of Contemporary International Relations (CICIR) (中国现代国际关系研究所 Zhongguo xiandai guoji guanxi yanjiusuo) (see Figure 4).

FIGURE 4: Chinese Estimates of Trends in Comprehensive National Power

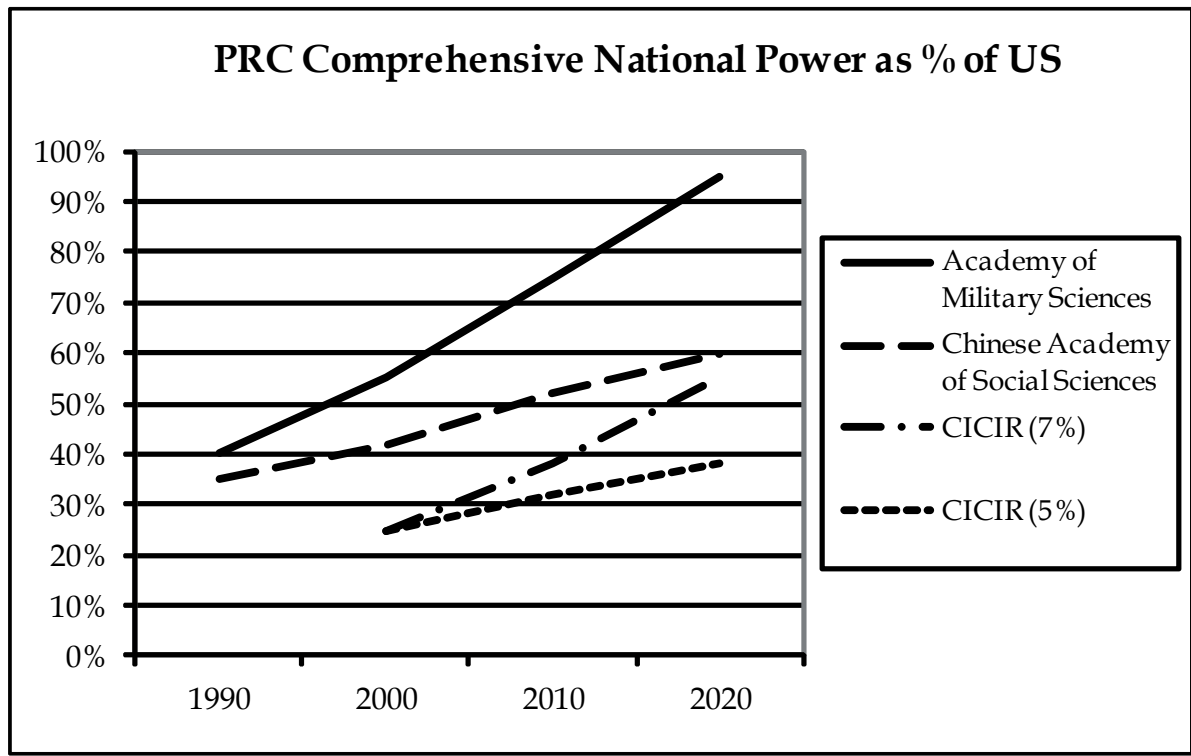

Sources: Johnston 2002, CICIR 2000.

Notes: " CIRIC (5\%)" refers to an estimate by the Chinese Institute of Contemporary International Relations ... that assumes a five percent growth in China's CNP and a three percent growth in American CNP. CICIR (7\%) [estimates] a seven percent growth rate for China's CNP' (Johnston 2002: 51). 


\section{TABLE 13: Chinese Academy of Social Sciences (CASS) CNP Indicators}

\begin{tabular}{|c|c|}
\hline \multirow[t]{4}{*}{ Natural resources } & $\begin{array}{l}\text { Manpower Resources: total population; life expectancy; proportion of } \\
\text { the economically active population in the total population; number of } \\
\text { university students per } 10,000 \text { people }\end{array}$ \\
\hline & $\begin{array}{l}\text { Land Resources: extent of national territory; amount of arable land; } \\
\text { forests }\end{array}$ \\
\hline & Mineral Resources (reserves): iron; copper; bauxite \\
\hline & Energy Resources (reserves): coal; crude oil; natural gases; water energy \\
\hline \multirow[t]{4}{*}{$\begin{array}{l}\text { Economic activities } \\
\text { capability }\end{array}$} & $\begin{array}{l}\text { Actual Economic Strength (per person): GDP per capita; industrial pro- } \\
\text { duction capability (electric energy production, steel output, cement } \\
\text { output, timber output); food supply capability (total grain output, av- } \\
\text { erage calories per capita); energy supply capability (volume of energy } \\
\text { consumption) }\end{array}$ \\
\hline & $\begin{array}{l}\text { Production Efficiency: social labour production rate; industrial labour } \\
\text { production rate, agricultural labour production rate }\end{array}$ \\
\hline & $\begin{array}{l}\text { Material Consumption Level: volume of energy consumption based on } \\
\text { GDP calculations }\end{array}$ \\
\hline & Structure: the proportion of the tertiary sector in total GDP \\
\hline \multirow{2}{*}{$\begin{array}{l}\text { Foreign economic } \\
\text { activities capability }\end{array}$} & Total import and export trade; total import trade, total export trade \\
\hline & $\begin{array}{l}\text { Total international reserves; international reserves (not including gold); } \\
\text { gold reserves }\end{array}$ \\
\hline $\begin{array}{l}\text { Scientific and techno- } \\
\text { logical capability }\end{array}$ & $\begin{array}{l}\text { Proportion of research and development in the GDP; number of sci- } \\
\text { entists and engineers; the number of scientists and engineers per } 1,000 \\
\text { people; proportion of machinery and transportation equipment exports } \\
\text { in total exports; proportion of high-technology-intensive exports in total } \\
\text { exports }\end{array}$ \\
\hline \multirow[t]{5}{*}{$\begin{array}{l}\text { Social development } \\
\text { level }\end{array}$} & $\begin{array}{l}\text { Education Level: education expenditures per capita; proportion of people } \\
\text { studying in higher education; proportion of people studying in second- } \\
\text { ary school education }\end{array}$ \\
\hline & $\begin{array}{l}\text { Cultural Level: adult literacy rate; number of people per one thousand } \\
\text { who get a daily newspaper }\end{array}$ \\
\hline & $\begin{array}{l}\text { Health Care Level: health care expenditures per capita; number of people } \\
\text { per doctor; number of people per nurse }\end{array}$ \\
\hline & $\begin{array}{l}\text { Communications: number of people who have a telephone per } 100 \text { peo- } \\
\text { ple }\end{array}$ \\
\hline & $\begin{array}{l}\text { Urbanization: Proportion of the urban population in the total popula- } \\
\text { tion }\end{array}$ \\
\hline Military capability & $\begin{array}{l}\text { Number of military personnel; military expenditures; weapons exports; } \\
\text { nuclear weapons (the number of nuclear launchers; the number of nu- } \\
\text { clear warheads) }\end{array}$ \\
\hline $\begin{array}{l}\text { Government regu- } \\
\text { lation and control } \\
\text { capability }\end{array}$ & $\begin{array}{l}\text { Proportion of final government consumption expenditures in the GDP; } \\
\text { proportion of central government expenditures in the GDP; investigation } \\
\text { through interviews asking nine questions }\end{array}$ \\
\hline $\begin{array}{l}\text { Foreign affairs capa- } \\
\text { bility }\end{array}$ & $\begin{array}{l}\text { Uses ten factors in a 'nerve network model' to carry out a broad assess- } \\
\text { ment }\end{array}$ \\
\hline
\end{tabular}

Sources: Pillsbury 2000, Wang 1996. 
TABLE 14: Comparison of AMS and CASS Projections of CNP and Rankings to 2020

\begin{tabular}{|l|c|c|c|c|c|c|c|c|}
\hline & \multicolumn{4}{|c|}{ AMS } & \multicolumn{4}{c|}{ CASS } \\
\hline Country & $\mathbf{1 9 8 9}$ & $\mathbf{2 0 0 0}$ & $\mathbf{2 0 1 0}$ & $\mathbf{2 0 2 0}$ & $\mathbf{1 9 9 0}$ & $\mathbf{2 0 0 0}$ & $\mathbf{2 0 1 0}$ & $\mathbf{2 0 2 0}$ \\
\hline \multirow{2}{*}{ USA } & 593.33 & 816.85 & $1,066.21$ & $1,391.71$ & 279 & 241 & 213 & 192 \\
& $(1)$ & $(1)$ & $(1)$ & $(1)$ & $(1)$ & $(1)$ & $(1)$ & $(2)$ \\
\hline \multirow{2}{*}{ USSR } & 386.72 & 648.34 & - & - & 184 & 131 & 121 & 108 \\
& $(2)$ & $(2)$ & & - & $(2)$ & $(5)$ & $(6)$ & $(9)$ \\
\hline \multirow{2}{*}{ Germany } & 378.10 & 558.23 & 772.36 & $1,068.63$ & 161 & 162 & 163 & 164 \\
& $(3)$ & $(3)$ & $(2)$ & $(3)$ & $(4)$ & $(3)$ & $(3)$ & $(3)$ \\
\hline \multirow{2}{*}{ Japan } & 368.04 & 537.39 & 736.35 & $1,009.00$ & 162 & 184 & 206 & 228 \\
& $(4)$ & $(4)$ & $(4)$ & $(4)$ & $(3)$ & $(2)$ & $(2)$ & $(1)$ \\
\hline \multirow{2}{*}{ France } & 276.35 & 384.93 & 507.36 & 668.73 & 129 & 141 & 150 & 157 \\
& $(5)$ & $(6)$ & $(5)$ & $(6)$ & $(5)$ & $(4)$ & $(4)$ & $(4)$ \\
\hline \multirow{2}{*}{ China } & 222.33 & 437.35 & 768.57 & 1350.63 & 94 & 102 & 110 & 118 \\
& $(6)$ & $(5)$ & $(3)$ & $(2)$ & $(9)$ & $(8)$ & $(8)$ & $(7)$ \\
\hline \multirow{2}{*}{ England } & 214.08 & 281.24 & 353.05 & 443.19 & 116 & 116 & 115 & 115 \\
& $(7)$ & $(7)$ & $(8)$ & $(8)$ & $(6)$ & $(7)$ & $(7)$ & $(8)$ \\
\hline \multirow{2}{*}{ Brazil } & 156.05 & 267.70 & 419.72 & 658.09 & 62 & 69 & 75 & 80 \\
& $(8)$ & $(9)$ & $(7)$ & $(7)$ & $(12)$ & $(12)$ & $(11)$ & $(11)$ \\
\hline \multirow{2}{*}{ India } & 144.16 & 274.08 & 468.15 & 799.67 & 51 & 53 & 55 & 57 \\
& $(9)$ & $(8)$ & $(6)$ & $(5)$ & $(13)$ & $(13)$ & $(13)$ & $(13)$ \\
\hline \multirow{2}{*}{ Canada } & 136.64 & 177.41 & 220.56 & 274.18 & 100 & 92 & 86 & 81 \\
& $(10)$ & $(10)$ & $(9)$ & $(9)$ & $(8)$ & $(9)$ & $(10)$ & $(10)$ \\
\hline \multirow{2}{*}{ Australia } & 112.59 & 147.91 & 185.67 & 233.07 & 78 & 71 & 66 & 62 \\
& $(11)$ & $(11)$ & $(10)$ & $(10)$ & $(10)$ & $(11)$ & $(12)$ & $(12)$ \\
\hline
\end{tabular}

Sources: Pillsbury 2000, Huang 1992, Wang 1996.

All of these results were projections made a decade or more ago. The Chinese Academy of Social Sciences publishes an annual 国际形势黄 皮书 Guoji zhengzhi huangpishu (Yellow Book of International Politics), that measures and updates - among other things - the economic, social, diplomatic and military power of 11 major nations: Brazil, Canada, China, France, Germany, India, Italy, Japan, Russia, United Kingdom and the United States. The results published for 2010 make it possible to compare the earlier CASS projections with the current statistical analysis, in accordance with the CASS indicators (see Table 15).

A recent study by US State Department official Richard M. Eason summarizes the Chinese concept of comprehensive national power and comments on its implications for the United States. He defines CNP as 'a quantifiable measurement...based...on measures of territory, natural resources, economic prosperity, diplomatic influence, international prestige, domestic cohesiveness, military capability, and cultural influence' and concludes: 
TABLE 15: CASS CNP Projections (1996)

\& Yellow Book Update (2010)

\begin{tabular}{|l|c|l|c|l|c|}
\hline \multicolumn{4}{|c|}{ CASS 1996 } & \multicolumn{2}{c|}{ CASS 2010 } \\
\hline 2000 Projection & 2010 Projection & \multicolumn{2}{l|}{ Yellow Book Update } \\
\hline Country & Rank & Country & Rank & Country & Rank \\
\hline US & 1 & US & 1 & US & 1 \\
\hline Japan & 2 & Japan & 2 & Japan & 2 \\
\hline Germany & 3 & Germany & 3 & Germany & 3 \\
\hline France & 4 & France & 4 & Canada & 4 \\
\hline Russia & 5 & Italy & 5 & France & 5 \\
\hline Italy & 6 & Russia & 6 & Russia & 6 \\
\hline UK & 7 & UK & 7 & China & $7(+1)$ \\
\hline China & 8 & China & 8 & UK & $8(-1)$ \\
\hline Canada & 9 & South Korea & 9 & India & $9(+4)$ \\
\hline South Korea & 10 & Canada & 10 & Italy & $10(-5)$ \\
\hline Australia & 11 & Brazil & $11(+1)$ & Brazil & 11 \\
\hline Brazil & 12 & Australia & $12(-1)$ & & \\
\hline India & 13 & India & 13 & & \\
\hline
\end{tabular}

Sources: Pillsbury 2000, Huang 1992, CASS 2010, cf. China Daily.

Throughout history, whenever a nation increases its strength and influence on the global level, other major powers must adjust. China is recovering from nearly two centuries of disruption and decline and is reasserting the major influential role it has had throughout much of history. This period of Chinese recovery will challenge the world's major powers, including United States. The U.S. will need to spend great effort in doing everything with [sic] its power to ensure that China's return to the world stage is peaceful. The U.S. must maintain a strong presence in East and Southeast Asia, not only military but diplomatic, economic and even cultural. The competition with China will be difficult and at times tense. However, China and the U.S. have many interests in common. The key is to continue to build on those interests through a competition in which both the two countries, and the world, benefit. A war between the world's two top economic powers would make the recent "Great Recession" look like a trial run for global economic catastrophe (Eason 2010).

The fact that Chinese strategists explicitly link their new theories of comprehensive national power to the ideas of ancient Chinese strategists, combined with the desire to measure it through the balance of both quantitative and qualitative factors as did the ancient strategists, demonstrates the continuity of a long-term perception of risk with Chinese characteristics. 


\section{Conclusions}

This study of China's perception of risk suggests the existence of a strong continuity over more than two millennia. Unlike the standard EuroAmerican view of risk, which calculates the probability of something happening and its cost should it happen, as well as possible risk management strategies, Chinese culture has traditionally had an aversion to risk, preferring harmony to disorder, and takes the methodology of analysis and calculation of risk of the ancient military treatise Sunzi Bingfa (The Art of War attributed to Sunzi) as a model for combining qualitative and quantitative factors in the development of various risk scenarios and various risk management strategies that are suitable to China's own culture and circumstances and designed both to avoid the worst and to achieve the best of any critical moment of risk. As a result, the analysis of domestic and foreign contexts that determine the type of risks that threaten the stability and development of China differs from the analysis resulting from the application of Euro-American paradigms, as evidenced by the comparative study of analyses of risks for the sustainability of Chinese growth presented here. The development of the concept of comprehensive national power, with its origins in Sunzi and other ancient military strategists, which many Chinese analysts see as their most important contribution to theories of international relations, demonstrates the continuity - and continuing validity - of the Chinese perception of risk.

Seán Golden is Professor of East Asian Studies and Director of the Institute of International and Intercultural Studies at Universitat Autònoma de Barcelona (UAB). (sean.golden@uab.es)

\section{NOTES}

1 Part of the research for this study has been financed by the Spanish government in the framework of Research Project FFI2008-05911 Procesos interculturales de Asia Oriental en la Sociedad Internacional de la Información: ciudadanía, género y producción cultural. INTERASIA. This study draws upon Golden 2010 and East Asia Net research workshops held at Lund University, Copenhagen Business School and Charles University in Prague.

2 Unless otherwise indicated, all translations by Seán Golden. 


\section{REFERENCES}

Ames, Roger T. (ed. and trans.) 1993. The Art of Warfare, New York: Ballantine.

Andersen, Benedict 2006. Imagined Communities. London, New York: Verso.

Anguiano Roch, Eugenio 2008. 'China como potencia mundial; presente y futuro' [China as a World Power, Present and Future] In China: radiografía de una potencia en ascenso, edited by Romer Cornejo. México, D.F.: El Colegio de México, Centro de Estudios de Asia y África.

Barmé, Geremie 1993. 'History for the Masses'. In Using the Past to Serve the Present, edited by Jonathan Unger. Armonk, NY: M.E. Sharpe, Inc. Available online at http:/ / www. tsquare.tv/themes/Histmasses.html (accessed 25 February 2011).

Bernstein, P.L. 1998. Against the Gods. The Remarkable Story of Risk. New York: John Wiley \& Sons.

Bosch-Domènech, Antoni and Joaquim Silvestre i Benach 2005. '¿Preparado para tomar riesgos? Evidencia experimental sobre la aversión y la atracción al riesgo' [Prepared to Take Risks? Experimental Evidence for Risk Aversion and Attraction]. Els opuscles del CREI. No. 16 (November).

CASS [Chinese Academy of Social Sciences, 中国社会科学院 Zhongguo Shehui Kexueyuan] 2010. 国际政治黄皮书 Guoji zhengzhi huangpishu [Yellow Book of International Politics]. Beijing: China Academy of Social Sciences.

China Daily (Web site), http://bbs.chinadaily.com.cn/viewthread.php?tid=656319 (accessed 13 September 2011).

CICIR [China Institutes of Contemporary International Relations,中国现代国际关系 研究所 Zhongguo xiandai guoji guanxi yanjiu suo] 2000. 综合国力评估系统研究报 告 Zonghe guoli pinggu xitong: yanjiu baogao [System for estimating comprehensive national strength: research report]. Beijing: China Institute of Contemporary International Relations.

Cooper, Robert 2000. The Post Modern State and the World Order. London: Demos.

Eason, Richard M. 2010. 'Enter the Dragon: China Regains Her Place in the World and A U.S. Strategy for Cooperation and Confidence Building'. Newport, RI: Joint Military Operations Department, Naval War College. Available at http://www. dtic.mil/cgi-bin/GetTRDoc?AD=ADA535540\&Location=U2\&doc=GetTRDoc.pdf ( accessed 4 March 2011).

Fung, Yu-Lan 1960. A Short History of Chinese Philosophy (Derek Bodde, ed.). London: Macmillan Paperbacks.

Galvany, Albert 2001. El arte de la guerra. Madrid: Editorial Trotta.

Golden, Seán 2010. 'La percepción del riesgo: Una visión desde China' [The Perception of Risk. A Vision from China]. Revista CIDOB d'Afers Internacionals, No. 89-90: 63-83.

Golden, Seán 2006. 'Socio-cultural aspects of the relationship between the EU and East Asia, with particular reference to China'. Asia Europe Journal, No. 4: 265-294.

Golden, Seán 2005. 'Percepciones y sistemas de valores como factores de desarrollo y transición en Asia' [Perceptions and Value Systems as Factors of Development and Transition in Asia]. In Desarrollo y transición en Asia, edited by S. Golden and M. Spoor, 157-175. Barcelona: Edicions CIDOB.

Golden, Seán 2004. 'Valores asiáticos y multilateralismo' [Asian Values and Multilateralism]. In Multilateralismo versus unilateralismo en Asia: el peso internacional de los 'valores asiáticos', edited by S. Golden, 103-132. Barcelona: Edicions CIDOB.

Golden, Seán and Marisa Presas (eds. and trans.) 2007. Sunzi. L'Art de la guerra. Barcelona: Publicacions de l'Abadia de Montserrat.

Griffith, Samuel B. (ed. and trans.) 1971. The Art of War. Oxford: Oxford University Press. 
Guo Chengwu 1975. Ancient Chinese Political Theories. Shanghai: The Commercial Press.

Hacking, Ian 1975. The Emergence of Probability: A Philosophical Study of Early Ideas about Probability, Induction and Statistical Inference. Cambridge: Cambridge University Press.

He Zhaowu and Bu Jinzhi 1998. An Intellectual History of China. Beijing: Foreign Languages Press.

Hsiao Kung-chuan 1979. A History of Chinese Political Thought. Princeton, NJ: Princeton University Press.

$\mathrm{Hu}$ Angang 胡鞍钢 2005a. 'Introduction: Building a Well-off Society in an All-round Way and Constructing a Harmonious Society'. Social Sciences in China. Special Issue: Studies of Building a Well-off Society and Harmonious Society in Transitional China, Winter: 84-86.

$\mathrm{Hu}$ Angang 2005b. 'Envisaging China's Grand Strategy: The Ambitious Goal of a Prosperous People and a Powerful Nation'. Social Sciences in China. Special Issue: Studies of Building a Well-off Society and Harmonious Society in Transitional China, Winter: 86-99.

$\mathrm{Hu}$ Angang (ed.) 2003. 中国大战略 Zhongguo Da Zhanlue [China's Grand Strategy]. Zhejiang: Renmin Chubanshe.

Hu Angang 胡鞍钢 and Men Honghua 门洪华 2002. 'The Rising of Modern China: Comprehensive National Power and Grand Strategy (1980-2000)'. Strategy and Management. No. 3.

Huang Shuofeng 黄硕风 1992. 综合国力论 Zonghe guoli lun [On comprehensive national power]. Beijing: Zhongguo shehui kexue chubanshe.

Johnston, A.I. 2002. 'The State of International Relations Research in China: Considerations for the Ford Foundation. International Relations Studies in China: A Review of Ford Foundation Past Grant-making and Future Choices, 2002'. Available online at http://www.irchina.org/en/pdf/IRSC_johnston_english.pdf (accessed 5 March 2011).

Kang, David C. 2005. China Rising: Peace, Power, and Order in East Asia. New York: Columbia University Press.

Lampton, David 2008. The Three Faces of Chinese Power. Might, Money and Minds. Berkeley, CA: University of California Press.

Leonard, Mark 2008. What does China Think? London: Fourth Estate.

Louie, Kam 1986. Inheriting Tradition: Interpretations of the Classical Philosophers in Communist China 1949-1966. Oxford: Oxford University Press.

Louie, Kam and Bob Hodge 1998. The Politics of Chinese Language and Culture. London: Routledge.

Maddison, Angus 2007. 'World Population, GDP and Per Capita GDP, 1-2008 AD'. The Groningen Growth and Development Centre (GDDC) (2007). Available online at http://www.ggdc.net/MADDISON/Historical_Statistics/horizontal-file_02-2010. xls (accessed 26 February 2011).

Maddison, Angus 2003. The World Economy: Historical Statistics. Paris: OECD.

Minford, John (ed. and trans.) 2002. The Art of War. New York: Viking.

Pillsbury, Michael 1999. 'PLA Capabilities in the 21st Century: How does China Assess Its Future Security Needs?' In The Chinese Armed Forces in the 21st Century, edited by Larry W. Wortzel, 89-158. Carlisle, PA: U.S. Army College, Strategic Studies Institute, December.

Pillsbury, Michael 2000. 'Geopolitical Power Calculations'. China Debates the Future Security Environment. Washington DC: National Defense University Press. Avail- 
able online at http:/ / www.fas.org/nuke/guide/china/doctrine/pills2/part08.htm (accessed 3 March 2011).

Porter, Michael et al. 2000. The Global Competitiveness Report 2000. New York: Oxford University Press.

Porter, Michael 1990. The Competitive Advantage of Nations. New York: The Free Press.

Qin Yaqing 2005. 'Theoretical Problematic of International Relationship Theory and the Construction of a Chinese School'. Social Sciences in China, 26(4): 62-72.

Ramírez, Laureano 2006. Arte de la guerra de Sunzi. Madrid: Editorial La Esfera de los Libros.

Spoor, Max and Seán Golden (eds.) 2006. Regionalismo y desarrollo en Asia. Procesos, modelos y tendencias. Barcelona: Edicions CIDOB.

Sunzi Bingfa. Sunzi bingfa, in 漢達文庫 CHANT (CHinese ANcient Texts) Database, The Chinese University of Hong Kong. Available at www.chant.org.

Voskressenski, Alexei D. 2005. 'The Rise of China and its Meaning for the Structure of Global Leadership in the 21st Century. A Russian Perspective'. European Security Forum, ESF Working Paper, No. 19 (April): 7-14.

Wade, Geoff 2004. 'The Zheng He Voyages: A Reassessment'. Asia Research Institute Working Paper Series, No. 31 (October). Available online at www.ari.nus.edu.sg/docs/ wps/wps04_031.pdf (accessed 13 September 2011).

Wang Hui 汪晖 2007. '¿Cómo interpretar "China" desde la "modernidad" ?' [How Do We Interpret 'China' from the Point of View of 'Modernity'?]. In Anuario Asia-Pacífico 2006, edited by O. Farrés, et al., 471-481. Barcelona: Fundación CIDOB, Casa Asia, Real Instituto Elcano.

Wang Songfen (ed.) 1996. 世界主要国家综合国力比较研究 Shijie zhuyao guojia zonghe guoli bijiao yanjiu [Comparative Study of the Comprehensive National Power of the Most Important Countries in the World]. Changsha: Hunan chubanshe.

Wen Tiejun 温铁军 2005. 'The relationship between China's strategic changes and its industrialization and capitalization'. In The Chinese Model of Development, edited by Tian Cao, 54-87. New York: Routledge.

Wu Chunqiu吴春秋 1995. 广义大战略 Guangyi da zhanlue [General Grand Strategy]. Beijing: Shishi chubanshe.

Yu Keping 俞可平 2009. 'Democracy is a Good Thing'. Essays on Politics, Society and Culture in Contemporary China. Washington DC: The Brookings Institution.

Zheng Bijian 郑必坚 2005. 'Diez puntos de vista sobre el ascenso pacífico de China y sobre las relaciones entre China y Europa' [Ten Points of View on China's 'Peaceful Rise' and Relations between China and Europe]. Madrid: Real Instituto Elcano. 